\title{
( The Wild Differences in Law when Trading in aße Wild Animals: a US and EU Perspective
}

\section{Malgorzata Lubelska-Sazanów}

Department of Private Law and Private International Law, University of Silesia in Katowice, POLAND

*E-mail for correspondence: malgorzata.lubelska@gmail.com

\begin{abstract}
This paper aims to show the differences between a regular animal trade and trade in wildlife in the European Union (EU) and in the United States (USA/US). Although the ideas towards using the international sale of animals are similar in the US legal system and in the EU legal system, they have very different foundations. The European model aims for policy - neutral rules of private international law agreed on a multilateral basis, whereas the American approach uses unilateral rules of private international law based on a country's own domestic interests. Even though there are still no binding international conflict of law rules that would apply to contracts between parties from the US and European countries, this problem could easily be solved in contract law by choosing the law applicable to the contract. However, though the conflict of law rules in the situation where one of the States of the USA is involved might be different in each case. That is the reason why the Convention on International Trade in Endangered Species of Wild Fauna and Flora (CITES) was drafted. Unfortunately, the conclusion based on the material presented in the article is that CITES is not effective enough. Therefore, although the law on the sale of animals leads to similar solutions in USA and in EU, even though it is based on different legal systems (common law and civil law countries), it leads to totally different solutions concerning the law on wild animals.
\end{abstract}

Keywords: civil law, contract law, sale of animals, wildlife trade, environmental law, international law

\section{INTRODUCTION}

It was not that long ago when a dentist from Minnesota killed the best-known and most beloved lion in Zimbabwe. ${ }^{1}$ Public opinion around the world was enflamed by this course of events. Social media was swamped with comments concerning the evil lurking in the "killer". This situation made it abundantly clear that most of society in developed countries is against killing wild animals. However, what about capturing them and keeping them in inadequate, appalling conditions?

The views of people in the postmodern culture of XXI century are truly complicated. One can easily get lost trying to find out what is considered right and what is considered wrong nowadays. Given the observation that society does not accept killing wild animals, there might be a serious problem for some people to understand why killing farm animals is widely accepted. In the same way, we can ask ourselves why is it right to keep dogs, cats and small parrots in our homes, but capturing and trying to domesticate birds of paradise is not. From the other side, if

${ }^{1}$ Rose George, The hunter who killed Cecil the lion doesn't deserve our empathy, The Guardian (July 29, 2015, 3:30 PM), the society is of one voice that wild animals deserve protection, why are people not disgusted when they think about keeping a little koala or beautiful blue ara at home?

This paper aims to show the differences between a regular animal trade and trade in wildlife in the European Union (EU) and in the United States (US). The two fields of law, which overlap on the subject of animal trade - private law regulating sale agreements and administrative law regulating wildlife trade - provide the best example of laws made by people with good ideas, but no will or power to enforce them.

\section{A Philosophical Background as Necessary Knowledge When Talking About Animal Welfare}

Although animal welfare is a broadly discussed problem nowadays, and the legal system provides higher standards of animal rights protection every year, it is still difficult to define precisely where the border is concerning wrongdoing to animals. killed-cecil-lion-walter-palmer. 
Jeremy Bentham, an English philosopher of XVIII century, the founder of the reforming utilitarian school of moral philosophy, incorporated the essential basis of moral equality into his system of ethics by means of the formula: "Each to count for one and none for more than one." 2 This formula was the foundation of the principle of equality, used by Peter Singer also to explain why animals deserve equal protection to human beings. ${ }^{3}$

According to Peter Singer, the basic element - taking into account the interests of the being, whatever those interests may be - must, according to the principle of equality, be extended to all beings, black or white, masculine or feminine, human or nonhuman. The author claims that animal liberation should be achieved globally and gives the example of Thomas Jefferson as a person who was responsible for writing the principle of the equality of men into the American Declaration of Independence. ${ }^{4}$ Peter Singer teaches us that equality between animals and human beings is something that should be accepted naturally, and it is just a matter of time before societies accept this - just as it was in the case against racism and in the case against sexism.

Jeremy Bentham wrote: "The day may come, when the rest of the animal creation may acquire those rights which never could have been withholden from them but by the hand of tyranny. The French have already discovered that the blackness of skin is no reason why a human being should be abandoned without redress to the caprice of a tormentor. It may come one day to be recognized, that the number of legs, the villosity of the skin, or the termination of the os sacrum, are reasons equally insufficient for abandoning a sensitive being to the same fate.. (...)." ${ }^{5}$

The philosophy presented already in the last century is growing stronger every day. All legislation in the matters of animal welfare protection is based on the idea that their suffering should be avoided. Although many legislators would probably disagree, I truly believe that a burning issue for the protection of our planet, as well as the

\footnotetext{
${ }^{2}$ The formula used by Jeremy Bentham has been misquoted in several sources - the closest variant to be found in his works is "Every individual in the country tells for one; no individual for more than one," which occurs in: John S. Mill, Rationale Of Judicial Evidence, Specially Applied To English Practice From The Manuscripts Of Jeremy Bentham 475, IV (book 8, chapter 29), (Hunt \& Clarke 1827). Cited after: Katarzyna De Lazari-Radek \& Peter Singer, The Point Of View Of The Universe: Sidgwick And Contemporary Ethics 349 (2014).

${ }^{3}$ Peter Singer, Wyzwolenie Zwierząt [Animal Liberation] 17 (Anna Alichniewicz, Anna Szczęsna trans., 2004).

${ }^{4}$ Id. at 18.

${ }^{5}$ Jeremy Bentham, An Introduction To The Principles Of Morals And Legislation 235-36, Clarendon Press Oxford 1907 (1823); Jeremy Bentham, Wprowadzenie Do Zasad Moralności I Prawodawstwa 418-20 (Bogdan R. Nawroczyński trans., 1958).

${ }^{6}$ Schweizerisches Zivilgesetzbuch [ZGB] [Civil Code], Dec. 10, 1907, SR 210, RS 210 (Switz.).

${ }^{7}$ A provision of a similar meaning, but not the same wording can be observed in almost all of the laws of the European countries, for example: Zákon č. 89/2012 Sb., občanský zákoník [Civil Code] § 494 (Czech), which underlines a special meaning of an animal and
}

problem of animal suffering and avoiding the extinction of endangered species are based on the philosophy of animal equality. All these issues are important for civil matters including for those connected with the trade of animals.

\section{Sale Of Animals- a Comparative Approach From The Perspective Of EU Countries}

The laws of most European states do not provide special regulations on the sale of animals. Such provisions were scratched out from the German and Swiss ${ }^{6}$ Civil Codes already in 2002. In other laws, such as Polish, the laws applicable to movables became applicable also to animals first in 2014. Indeed, in most European countries we can observe a trend to unify the sale provisions concerning animals and other movables. On the other hand, all state laws, serving herein as an example of European legislation, include also a provision stating that "animals are not things 7 ", although some legal systems - like Germany, Austria and Switzerland - include this provision inside their Civil Codes and some - like Poland - include it elsewhere. ${ }^{8}$

Although some differences between the European legislation can be found, almost none of them include special provisions concerning the sale of animals, and imply that the provisions applicable to the sale of movables should be used - taking into account the nature of animals, and only as long as it does not contradict this nature. Also common for all these legislations are the remedies that can be claimed in the situation when a purchased animal turns out to have some defects (for example: illness, the lack of certain characteristics claimed by the seller, etc.). In that case, the buyer may terminate the contract, demand a price reduction, or accept the seller's attempt to remove the defect. $^{9}$

The similarity of the remedies and legal solutions in the various European countries is an effect of legal harmonization. ${ }^{10}$ According to Article 288 of the Treaty on

provides that other provisions applicable to movables can be applied to animals only if it does not contradict its nature.

${ }^{8}$ See: [BGB] § 90a (Ger.); [ZGB] § 641a (Switz.); Ustawa o ochronie zwierząt [Bill of Animal Rights] Art. 1, Aug. 21, 1997, Dziennik Ustaw [DZ.U.] $1997 \mathrm{nr} 111$ poz. 724, as amended (Pol.); Allgemeines Bürgerliches Gesetzbuch [ABGB] [Civil Code], Justizgesetzsammlung 946/1816, as amended, § 285a (Austria).

${ }^{9}$ The seller may remove the defect by removing it from a particular good or by providing a different good without defects - this possibility, however, is rarely for animals. The reason for this is the fact that defects can almost never be removed from an animal with any certainty, and as the buyer - usually emotionally connected with a particular animal - would probably not be willing to exchange it for a different one. See, e.g: the German case, where the petitioner claimed that the purchased horse did not have the characteristics established between the parties and asked for a $50 \%$ reduction: Bundesgerichtshof [BGH] [Supreme Court] Jan. 9, 2008, Az. VIII ZR 210/06 (Ger.).

${ }^{10}$ To learn more about the harmonization of law in EU, see: The Europeanisation Of International Law: The Status Of International Law In The Eu And Its Member States (Jan Wouters, André Nollkaemper, Erika de Wet eds., 2008 ); Theory And Practice Of Harmonisation (Mads Andenas, Camilla Baasch Andersen eds., 
the Functioning of the European Union (TFEU), ${ }^{11}$ "to exercise the Union's competences, the institutions shall adopt regulations, directives, decisions, recommendations and opinions." These legislative acts of EU provide legal harmonization between EU Member States.

A very important legal act in EU is the Rome I Regulation, ${ }^{12}$ which relates to civil relations with a cross-border impact. ${ }^{13}$ Article 3 of this act provides that "a contract shall be governed by the law chosen by the parties," ${ }^{14}$ and Article 4 includes directions to the law applicable in the absence of choice and provides in section a), that "a contract for the sale of goods shall be governed by the law of the country where the seller has his habitual residence." ${ }^{15}$ Given that the provisions of law of the European States set out that the rules applicable to the sale of movables also apply to the sale of animals, the laws on moveables presented herein also constitute the foundation of a European conflict of laws rule concerning the sale of animals.

Although Rome I Regulation is the main source of the conflict of laws solutions concerning sales law in the EU, other legal acts of EU also deal with harmonization within the Member States. ${ }^{16}$ Therefore, it is important to differentiate between material rules of private

2012); Isidora Malétic, The Law And Policy Of Harmonisation In Europe's Internal Market, (Edward Elgar Pub 2013); Monika Domańska, Implementacja Dyrektyw Unijnych Przez Sądy Krajowe (2014); European Union Law (Catherine Barnard, Steve Peers eds., 2014).

${ }^{11}$ Consolidated versions of the Treaty on European Union and the Treaty on the Functioning of the European Union 1 - 390, Oct. 26, 2012, O. J. (C 326) 01.

${ }^{12}$ Regulation (EC) No 593/2008 of the European Parliament and of the Council of June 17,2008 on the law applicable to contractual obligations (Rome I Regulation), 6 - 16, July 4, 2008, O. J. (L 177) .

${ }^{13}$ Read more: Ulrich Magnus, Francesca Ragno, George A. Berman in Rome I Regulation: The Law Applicable To Contractual Obligations In Europe 27 - 50, 129 - 70, 349 - 58 (Franco Ferrari, Stefan Leible eds., 2009); C. G. J. Morse in Chitty On Contracts para. 30-129 until 30-303 (Hugh G. Beale, Joseph Chitty eds., 2012).

${ }^{14}$ Rome I Regulation 9-10, July 4, 2008, O. J. (L 177).

${ }^{15}$ Id.

${ }^{16}$ Elizabeth B. Crawford \& Janeen M. Carruthers, Connection and coherence between and among European instruments in the private international law of obligations, 63 International And Comparative Law Quarterly 1, 1- 29 (2014).

${ }^{17}$ To learn more about the rules of private international law and conflict of law rules, see: Ewa Rott-Pietrzyk in System Prawa Prywatnego Międzynarodowego Vol. 20a 252 - 58 (Maksymilian Pazdan ed., 2014).

${ }^{18}$ Prawo Prywatne Międzynarodowe [PPM] [Private International Law Act], Feb. 4, 2011, J. L. of 2011 nr 80 poz. 432 (Pol.). Note that, in order to respect the law created by the EU Institutions, this legal act does not provide any rules applicable for contractual obligations. Thus, this issue is regulated in Rome I Regulation.

${ }^{19}$ E.g. the Council of Europe European Convention on Human Rights, as amended, Nov. 4, 1950, C.E.T.S. 155; The Council of Europe Civil Law Convention on Corruption, as amended, Nov. 4, 1999, C.E.T.S. 174 and several other conventions.

${ }^{20}$ So-called soft law acts, such as UPICC, PECL or DCFR. The first version of UPICC was published in 1994, see: UNIDROIT Principles of Commercial Contracts, Rome 1994. The second version was published in 2004 and the third in 2010. To learn more about UPICC, see: international law and conflict of law rules. ${ }^{17}$ Thus, these two types of rules constitute the foundations of European Private International Law.

The conflict of law rules comprise legal acts of various sources, such as the laws of the European countries (each EU Member State has its own legal act named "Private International Law", though the provisions need to respect the law created by the EU Institutions, e.g. Polish Private International Law of $2011^{18}$ ), as well as European legal acts and International Conventions. On the other hand, the material rules of private international law comprise material rules placed in International Conventions ${ }^{19}$ model law acts $^{20}$ and - although it remains questionable - also in the Common European Sales Law. ${ }^{21,22}$

Aside from these regulations (as presented above on the example of Rome I Regulation), there are different means to express the European conflict of law rules (also in reference to animals) in the form of directives. These are legal acts of the European Union that impose obligations on the Member States to achieve a certain legal result, without dictating strict legal aims to achieve it. ${ }^{23}$ Certain directives set out minimal standards for animal protection

Bernadetta Fuchs in System Prawa Handlowego, Vol. 9 60-3 (Wojciech Popiołek ed., 2013). The first part of PECL comes from 1995: The Principles Of European Contract Law. Part I. It was revised and united with the second part and published with a commentary in 2000: Principles Of European Contract Law. Parts I And II Combined And Revised. The third part of PECL was published in 2003 under the name The Principles Of European Contract Law. Part Iii. To learn more about PECL, see: Ewa Rott-Pietrzyk in System Prawa Handlowego, Vol. 9 50-60 (Wojciech Popiołek ed., 2013). To learn more about DCFR, see: Principles, Definitions And Model Rules Of European Private Law. Draft Common Frame Of Reference (DCFR), Interim Outline Edition And Principles, Definitions And Model Rules Of European Private Law. Draft Common Frame Of Reference (DCFR), Full Edition, available at: http://ec.europa.eu/justice/contract/files/european-private-

law_en.pdf (July 4, 2016). To learn more about DCFR, see also: Ewa Rott-Pietrzyk in System Prawa Handlowego, Vol. 9 69-79 (Wojciech Popiołek ed., 2013).

${ }^{21}$ The final version of CESL Project, Eur. Parl. Doc. (COM 2011, 635 final), Eur-Lex Website (2015), http://eurlex.europa.eu/LexUriServ/LexUriServ.do?uri=COM:2011:0635:FIN: en:PDF.

22 Ewa Rott-Pietrzyk in System Prawa Prywatnego Międzynarodowego Vol. 20A 252 - 53 (Maksymilian Pazdan ed., 2014).

${ }^{23}$ Compare: Treaty on the Functioning of the European Union (further: TFEU) Art. 288 (3), providing, that an EU Directive is a legislative instrument addressed to Member States and not to private individuals are directly applicable and binding on one hand and Art. 288 (2) TFEU, providing that it is also a directly applicable and generally binding legal act on the other hand. That results in the fact that an individual that has been hurt by an incorrect transposition of a directive into national law is entitled to bring the Member State responsible for that failure before the Court of Justice of the European Union (CJEU). Read more: Nigel Foster, Foster On Eu Law 108 (Oxford 2015); Martin Hedemann-Robinson, Enforcement Of European Union Environmental Law: Legal Issues And Challenges 318 (2nd ed., 2015). 
in reference to their use for particular purposes ${ }_{,}^{24}$ some of them unify standards for keeping animals in all EU Member States, ${ }^{25}$ and some of them set standards for the protection of animals that have never been set before. ${ }^{26}$

\section{InTERnational Sale Of ANimals - The "US ApProACH" Versus The "EUROPEAN APPROACH"}

Similar ideas towards using the international sale of animals can be observed in the United States (USA/US) legal system, but with very different foundations. The problem of the rules applicable to the international sale of animals in the US should not be underestimated, given that this country leads the world in global meat consumption per capita. ${ }^{27}$ Although the main focus further in this section of this article will be given to international wildlife trade, which has lately become an inconvenient and incoherent issue, it is important to know the reason why the international sale of farm animals is so common ${ }^{28}$ in the US.

The interstate and international sale of animals, not subject to any legal restrictions and governed by the rules of private international law, are very different in the "European" and in an "American" model. ${ }^{29}$ The European model aims for policy - neutral rules of private international law agreed on a multilateral basis, whereas the American approach uses unilateral rules of private international law based on a country's own domestic interests..$^{30}$ Although there are still no binding international conflict of law rules ${ }^{31}$ that would apply to contracts between parties from the US and European countries, this

${ }^{24}$ See, e.g.: European Council Directive 2008/119/EC of December 18, 2008 laying down minimum standards for the protection of calves; European Commission Directive 2001/93/EC of November 9, 2001 amending Directive 91/630/EEC laying down minimum standards for the protection of pigs; European Council Directive 2007/43/EC of June 28, 2007 laying down minimum rules for the protection of chickens kept for meat production.

${ }^{25}$ European Council Directive 98/58/EC of July 20, 1998 concerning the protection of animals kept for farming purposes.

${ }^{26}$ See, e.g.: Directive 2010/63/EU of the European Parliament and of the Council of September 22, 2010 on the protection of animals used for scientific purposes.

${ }^{27}$ Monica Engebretson in Long Distance Transport And Welfare Of Farm Animals 220-221 (Michael C. Appleby and others eds., 2008).

${ }^{28}$ Notwithstanding that, according to the Organization for Economic Co-operation and Development document: Agriculture, Trade And The Environment (2003), the largest foreign market for US live pigs is Mexico, note that most farm animal sale agreements occur between parties with their registered offices in different States - see: Monica Engebretson in Long Distance Transport And Welfare Of Farm Animals 220 (Michael C. Appleby and others eds., 2008). Sale agreements between parties from different States also lead to a conflict of law problem.

${ }^{29}$ See: Mathias Reimann, Comparative Law and Private International Law, in The Oxford Handbook Of Comparative Law 1363-96 (Mathias Reimann, Reinhard Zimmermann eds., 2006).

${ }^{30}$ Mathias M. Siems, Comparative Law 227 (2014).

${ }^{31}$ Still, there are many model law rules that show a vivid interest in a global Unification of Conflict Laws. See, e.g.: Hague Principles on Choice of Law in International Commercial Contracts (first approved in March 2015), as well as significant works of the United Nation Commission's on International Trade Law (UNCITRAL). It is worth problem could easily be solved in contract law by choosing the law applicable to the contract. However, though the conflict of law rules in the situation where one of the States of the USA is involved might be different in each case, ${ }^{32}$ and also concerning every issue of a single case (for example - rules applicable to the formation of the contract, rules applicable to its performance, termination, etc.) $)^{33}$

Luckily, the countries already made attempts to govern the rules on the wildlife trade of animals back in the 1960s. That is how the Convention on International Trade in Endangered Species of Wild Fauna and Flora (CITES) was drafted. ${ }^{34}$ The Convention was drafted as a result of a resolution adopted in 1963 at a meeting of members of IUCN (The World Conservation Union). The text of the Convention was finally agreed at a meeting of representatives of 80 countries in Washington, D.C. on March 3, $1973^{35}$ and CITES entered in force on July $1,1975 .{ }^{36}$ Thus, there are international administrative rules governing the trade in wildlife. Therefore, the only issue where liability based on the rules of private international law may arise in reference to this type of trade is a contractual liability for selling an animal protected under CITES without the Buyer's knowledge.

\section{CITES - WhAT IS IT AND DOES IT WORK At ALL?}

As mentioned, the most important moment for the protection of endangered species was the year 1975 when CITES $^{37}$ entered into force. CITES has two essential goals: to reduce the harmful effects of commercial trade on

mentioning that one of them - The United Nations Convention on Contracts for the International Sale of Goods - is already directly binding on the parties, though it is only applicable in Business to Business relations.

${ }^{32}$ See, e.g.: 28 U.S. Code [USC] § 1350. Read more: Mathias M. Siems, Comparative Law 227-30 (2014).

33 In reference to the conflict of law rules in the US, see: Gary J. Simson, Issues And Perspectives In Conflict Of Laws: Cases And Materials (Carolina Academic Press, 2014); John O. Haley, Fundamentals Of Transnational Litigation: The United States, Canada, Japan, And The European Union (Carolina Academic Press, 2014). In reference to jurisdiction based on activities in the forum unrelated to the litigation and to personal jurisdictions see also articles: Charles W. Rhodes, Nineteenth Century Personal Jurisdiction Doctrine in a Twenty-First Century World, 64 Florida Law Review 387 (2012); Allan R. Stein, The Meaning of "Essentially at Home" in Goodyear Dunlop, 63 South Carolina Law Review 527, 527 (2012).

${ }^{34}$ CITES, https://cites.org/eng/disc/what.php (last visited July 11, 2016).

${ }^{35}$ CITES, https://cites.org/eng/disc/what.php (last visited July 11, 2016)..

${ }^{36}$ See the list of contracting parties, downloaded on March 6, 2016 from the website: https:/ /cites.org/eng/disc/parties/chronolo.php

${ }^{37}$ To learn more about CITES see for example: Environmental Investigation Agency, http://eia-global.org/campaigns/forestscampaign/u.s.-lacey-act/lacey-and-cites (last visited July 11, 2016); CITES https://cites.org/eng/disc/what.php (last visited July 11, 2016).; Human Society International,

http://www.hsi.org/campaigns/dont_buy_wild/faqs_about_cites. html (last visited July 11, 2016). 
threatened or endangered species of fauna and flora, and to establish a worldwide system for ensuring that trade in other species is conducted on a sustainable basis for the future ${ }^{38}$ Although it is obvious nowadays that endangered species deserve protection, this idea was quite new in the 70s when the work on CITES begun. CITES is the only convention that seeks to protect wildlife solely by the regulation of international trade, and leading commentators call it often the most successful of all international treaties concerned with the conservation of wildlife. ${ }^{39}$

The treaty contains three appendices on which species are placed. The species found in Appendix I are threatened with extinction and the parties to the treaty agree to ban all international commercial trade in that species. The species placed in Appendix II are not necessarily threatened with extinction, but they may become so unless trade is closely controlled. Appendix II also includes species that look like other species already listed in Appendix I or Appendix II. The parties to the treaty agree to allow trade in the species listed in Appendix II only if certain conditions are met. A species on Appendix III is one that is protected in at least one country, which has asked other parties to CITES for assistance in controlling the trade. ${ }^{40}$

CITES was initially connected mainly with the protection of mammals, such as elephants, ${ }^{41}$ rhinos $^{42}$ and big cats. ${ }^{43}$ Nowadays, however, CITES is becoming increasingly accepted also, for example, as a tool to demonstrate and monitor the legality of trade in timber species listed in the Appendices of the Convention. ${ }^{44}$ Although CITES is known round the world and its role in the protection of endangered species cannot be underestimated, there are concerns whether it really changes the fate of endangered species. ${ }^{45}$ I think that the question whether there we need a better, more modern protection of wildlife is worth answering. Thus, an attempt to answer that question will

\footnotetext{
${ }^{38}$ Anupam Goyal, The Wto And International Environmental Law, New Delhi, 2006, p. 144.

${ }^{39}$ Id. at 84; Simon Lyster, International Wildlife Law 240 (Grotius Publications. Ltd., 1985); Stefan Carpenter, The devolution of conservation: why cites must embrace community-based resource management, 2 Arizona Journal Of Environmental Law \& Policy 1, 35 (2011). About CITES' effectiveness in general, see: R. B. Martin, When CITES Works and When it Does Not, in Endangered Species, Threatened Convention: The Past, Present And Future Of CITES (Jon Hutton, Barnabas Dickson eds., 2000).

${ }^{40}$ The Human Society International,

http://www.hsi.org/campaigns/dont buy wild/faqs about cites. html (last visited July 11, 2016).

${ }^{41}$ See more about ivory trade: Sarah Fitzgerald, International Wildlife Trade: Whose Business Is It? 61-77 (1989).

${ }^{42}$ R. B. Martin, When CITES Works and When it Does Not, in Endangered Species, Threatened Convention: The Past, Present And Future Of CITES 29-37 (Jon Hutton, Barnabas Dickson eds., 2000).

${ }^{43}$ Sarah Fitzgerald, International Wildlife Trade: Whose Business Is It? 37-38 (1989).

${ }^{44}$ Read more about timber trade in: Sara F. Oldfield, The Evolving Role of CITES in Regulating the International Timber Trade, 22 Review Of
}

be developed in the final conclusions, after presenting the whole spectrum of the problem of wildlife trade.

As CITES is legally binding on the parties, each party has to adopt it into national law in order to enforce the treaty. Thus, it is a basic principle of international law that a State party to an international treaty must ensure that its own domestic law and practice are consistent with the provisions of the treaty. ${ }^{46}$ In the US, CITES is implemented and enforced primarily through the Endangered Species Act and in Europe through two regulations: Council Regulation (EC) No 338/97 of December 9, 1996 on the protection of species of wild fauna and flora by regulating trade therein, including the annexes containing a list of species regulated in trade (the framework regulation) and Commission Regulation (EC) No 865/2006 of May 4, 2006 laying down detailed rules concerning the implementation of Council Regulation (EC) No 338/97 on the protection of species of wild fauna and flora by regulating trade therein (the implementing regulation). ${ }^{47}$ As Article 288 TFEU makes EU regulations "directly applicable", any further transposition into the national law of each European country is not needed. Thus, the EU regulations can be relied upon in a national court as a cause of actions. ${ }^{48}$

\section{Are Exotic Pets Always Wildlife? - The USA Perspective}

According to a survey made by the American Pet Products Association, in 2015 66\% of American households had at least one pet. ${ }^{49}$ However, nobody conducted such a survey concerning "exotic pets", and I am afraid that the government would not be satisfied by its result. Exotic pets are not only prairie dogs and hedgehogs, but also giraffes, pythons and tigers. Unfortunately, that is not a myth and the data provided by the Humane Society of the US inform the public about definitely too many tragedies caused by wild animals kept in captive. For example, between 1990

European Comparative \& International Environmental Law 291-300 (2013).

${ }^{45}$ See, e.g.: R. B. Martin's article: R. B. Martin, When CITES Works and When it Does Not, in Endangered Species, Threatened Convention: The Past, Present And Future Of CITES 29-37 (Jon Hutton, Barnabas Dickson eds., 2000).

${ }^{46}$ In reference to the implementation of International Conventions, see United Nations website (here, on the issue of the implementation the Convention on the Rights of Persons with Disabilities and its Optional Protocol (A/RES/61/106). United Nations, http:/ / www.un.org/disabilities/default.asp?id=235 (last visited July 11, 2016).

47 European Commission, An Introduction to CITES and its Implementation in the European Union (2010),

http:/ / ec.europa.eu/environment/cites/pdf/trade_regulations/sho rt_ref_guide.pdf;

http:/ /ec.europa.eu/environment/cites/legislation_en.htm.

${ }^{48}$ See e.g.: Dermot Cahill, Niamh Connery, Tp Kennedy, Vincent Power, European Law 87 ( 2011).

${ }^{49}$ Humane Society Of The United States, http://www.humanesociety.org/issues/pet_overpopulation/facts/ pet ownership statistics.html (last visited July 11, 2016). 
and 2013, five people were killed and more than 40 others injured (sometimes left permanently disabled) by attacks from captive bears, ${ }^{50}$ and more than 230 people have been injured by attacks from primates in the US. ${ }^{51}$ Moreover, there are an estimated 15,000 primates alone kept as pets in the US, ${ }^{52}$ with the exotic pet trade as a whole doing business of $\$ 10-15$ billion a year in that country alone. ${ }^{53}$

Because of the dispersion of animal laws in State and Federal regulations in the USA, it is not possible to set any general rules. ${ }^{54}$ Therefore, the first place to look for regulations applicable to exotic pets is at the local level, which means city, town and county ordinances. The reason for this is the fact that keeping wild animals as pets is mostly considered as an issue of public health and safety, as well as an issue of combatting nuisance. ${ }^{55}$

As a second step, the state laws should be considered, although - as already mentioned - they vary from state to state. There are states that have no laws of keeping wild animals as pets at all (for example Nevada, Wisconsin and Alabama), some that require special permits (for example Arizona, Tennessee, Florida) and some that ban the possibility of keeping any wild animals as pets (for example California, Oregon and Illinois). ${ }^{56}$ Oregon, which is known for rigorous laws in this matter, has included in its statute a general policy to protect the public against the health and safety risks that exotic animals pose to the community, to ensure the health, welfare and safety of exotic animals and to ensure the security of facilities in which exotic animals are kept. ${ }^{57}$ On the contrary, all felines except for bobcats and mountain lions are exempt from permit requirements in Nevada. ${ }^{58}$ Furthermore, although

50 Humane Society Of The United States, http://www.humanesociety.org/issues/exotic pets/facts/dangero us-exotic-pets-bears.html (last visited July 11, 2016).

${ }^{51}$ Humane Society Of The United States,

http://www.humanesociety.org/issues/exotic_pets/facts/dangero us-exotic-pets-primates.html (last visited July 11, 2016).

${ }^{52}$ Id.

${ }^{53}$ Katherine Hessler, Tanith Balaban, Exotic Animals as Pets, GPSOLO (2009), available at:

http://www.americanbar.org/newsletter/publications/gp_solo_ma gazine_home/gp_solo_magazine_index/exoticpets.html.

${ }^{54}$ What clearly shows transparent differences in the attitude to harmonization of national/State laws in US and in Europe.

${ }^{55}$ Katherine Hessler, Tanith Balaban, Exotic Animals as Pets, GPSOLO (2009), available at:

http://www.americanbar.org/newsletter/publications/gp_solo_ma gazine_home/gp_solo_magazine_index/exoticpets.html.

56 Humane Society Of The United States, http://www.humanesociety.org/assets/pdfs/wildlife/exotics/state -laws-dangerous-wild-animals.pdf (last visited July 11, 2016).

${ }^{57}$ West's Oregon Revised Statute [ORS] § 609.309 (2015).

${ }^{58}$ Big Cat Rescue Organization: http://bigcatrescue.org/state-lawsexotic-cats / (last visited July 11, 2016).

${ }^{59}$ Nevada Revised Statute [NRS] 503.597 (2015).

${ }^{60}$ NRS 501.3855 provides a civil penalty of $\$ 5,000$ to $\$ 30,000$ for an illegal possession of big game mammals, moose, bobcats, swans and eagles, and $\$ 250$ to $\$ 5,000$ for other wildlife. However, it is important to take into account that Nevada Administrative Code [NAC] 424.590 (2015) provides that "exotic or potentially dangerous pets or other
Nevada Statute prohibits the import of any aquatic life or wildlife, ${ }^{59}$ fees are only imposed for the 'unlawful possession of wildlife,' without specifying the legal meaning of this term. ${ }^{60}$ As has already been shown in this article, state laws can be misleading - even for the courts, as happened in the case City of Columbia v. K. Henderson, which considered the legality of Mr. Henderson keeping two alligators - "Snuggles" and "Babe". ${ }^{61}$

The federal legislation is broader than state and local legislations, but limited to regulating certain issues (such as ownership, transportation, import and export of captive animals) through interstate commerce and foreign policy. It affects breeders and sellers of exotic animals more than owners of exotic pets (who should pay more attention to local legislations). ${ }^{62}$ Wild animals may require a license from the U.S. Department of Agriculture (USDA) ${ }^{63}$ and imports might be subject to inspection by the U.S. Fish and Wildlife Service (FWS) and the U.S. Department of Agriculture's Animal and Plant Health Inspection Services (APHIS).

Concerning federal legislation, the most important act is the Endangered Species Act (ESA), ${ }^{64}$ which was enacted in order to implement CITES into US law. Although the ESA prohibits a person from possessing any endangered species of fish or wildlife and it is unlawful for a person to trade or possess any species traded in violation of CITES, ${ }^{65}$ one should remember that not all exotic pets are endangered species. Unlike many other federal environmental acts, the ESA responsibilities are non-delegable to states. ${ }^{66}$ However, that might also be the reason behind the accusations that the ESA is a politically influenced act ${ }^{67}$ - the classical case Tennessee Valley Authority v. Hill ${ }^{68}$ was one of the first cases

animals are prohibited unless the licensee has obtained any required permit or license to keep the pet or animal and has provided the licensing authority with a written plan documenting the reasons that the pet or animal does not present a threat to the safety of a child in the home."

${ }^{61}$ City of Columbia v. K. Henderson, 399 S.W.3d 493 (Mo. App. W.D. 2013).

${ }^{62}$ Katherine Hessler, Tanith Balaban, Exotic Animals as Pets 44, GPSOLO (2009), available at:

http://www.americanbar.org/newsletter/publications/gp_solo_ma gazine_home/gp_solo_magazine_index/exoticpets.html.

${ }^{63}$ For example, such a license allows the existence of Texan online shop, licensed with the USDA under the Animal Welfare Act, which sells various sorts of Pythons - e.g. a Tiger Reticulated Python for \$ 600 and a Banana Black Pastel Pinstripe Python for $\$ 1.500$

${ }^{64}$ Endangered Species Act of 1973 [ESA] (2015).

${ }^{65}$ ESA Sec. 4 a) (2) in combination with ESA Sec. 9 a).

${ }^{66}$ See: ESA Sec. 7.

67 See, e.g.: United States Government Accountability Office, Testimony before the Committee on Natural Resources, House of Representative, Statement of of R. Nazarro, Endangered Species Act Decision Making 1; Tim Forsyth, The Political Ecology of the Ecosystem Approach for Forests, in Forests In Landscapes: Ecosystem Approaches For Sustainability 165-76 (Jeffrey Sayer, Stewart Manginnis Michelle Laurie eds., 2005); Bonnie Harllee, Myungsup Kim, Michael Nieswiadomy, Political Influence on Historical ESA Listings by State: A Count Data Analysis, 140 Public Choice 21, 21-42 (2009).

${ }^{68}$ Tennessee Valley Authority v. Hiram Hill et al., 437, U.S. 153 (1978). 
to prove this fact. Although the ESA constitutes solid foundations for animal protection, its impact on animal welfare is not as effective as one may assume. For example, as a result of the CITES listings for big cats, most merchants focused on smaller cats, like the ocelot and lynx. ${ }^{69}$ However, there is a legal act much younger and more effective than ESA, namely the USA Wild Bird Conservation Act of 1992, ${ }^{70}$ which is the main reason for the low numbers of birds traded to the USA. ${ }^{71}$ Aside from the federal legislation, it is important for importers and exporters to obey several rules set by FWS - they need to use designated ports, declare a shipment though a special FWS Form, ${ }^{72}$ and in most cases be licensed though the FWS and pay certain fees with each shipment. ${ }^{73}$ Still, what is to be underlined in the end is that there are no federal laws that regulate or prohibit keeping exotic animals as pets.

\section{Can Exotic Animals Be Pets In Europe?}

Before presenting the European legal acts on wildlife protection, it is worth mentioning that the preliminary history of the European Union began first after the Second World War, the last enlargement by a significant number of states occurred only in 2004, and new countries are still accessing the EU, ${ }^{74}$ which makes this Union a quite young, but a very successful political creation. Therefore, it is very important to bear in mind that the protection of plant and animal species in the EU has undergone a long evolution since the beginnings of the European Community. The last significant change to environmental law in the primary law of the EU was introduced in 2007 with the Treaty of Lisbon. ${ }^{75}$ Namely, the newly introduced Articles 191 to 193 set out

\footnotetext{
${ }^{69}$ Sarah Fitzgerald, International Wildlife Trade: Whose Business Is It? 38 (1989).

${ }^{70}$ Wild Bird Conservation Act [WBCA], J. L. of 1992 nr 102-440, 16 U.S.C. 4901 - 4916.

${ }^{71}$ Maylynn Engler, Rob Parry-Jones, Opportunity or Threat - the Role of the European Union in Global Wildlife Trade (2007), available under: https: / / www.google.pl/url?sa =t\&rct=j\&q=\&esrc $=$ \&\&source=web\&c $\mathrm{d}=1 \&$ ved=0ahUKEwiQ5e_RjuzNAhXsIpoKHdMaB2AQFggiMAA\& url =http $\% 3 \mathrm{~A} \% 2 \mathrm{~F} \% 2 \mathrm{Fstatic1.1.sqspcdn.com} \% 2 \mathrm{Fstatic} \% 2 \mathrm{Ff} \% 2 \mathrm{~F} 157301$ \%2F2327381\%2F1231166092210\%2Ftraffic_pub_trade15.pdf\%3Ftoken \%3D7jSJGvv2Yf3U6tJJ502OBK8GyjI\%253D\&usg=AFQjCNHTkYiLN ouuE-zngQO4CidS6XElrQ\&sig2=JQD-oCBTsRk-XJRVTivIgA.

${ }^{72}$ FWS Form 3-177 - Declaration for Importation or Exportation of Fish or Wildlife.

${ }^{73}$ See: U.S. Fish And Wildlife Service, www.fws.gov (last visited July 11, 2016).

${ }^{74}$ After 2004, the next two countries became EU members in 2007, and the last country to access the EU was Croatia in 2013. However, at the time of publishing this article, there are still a further six countries recognized as candidates for membership. For more information, see: http:/ / europa.eu (last visited July 11, 2016).

${ }^{75}$ Treaty of Lisbon amending the Treaty on European Union and the Treaty establishing the European Community, Dec. 13, 2007, O. J. (C 306) 01.

${ }^{76}$ Ludwig Kraemer, EU Environmental Law 181 (2012).

${ }^{77}$ According to Art. 13 TFEU, introduced by the Treaty of Lisbon, "In formulating and implementing the Union's agriculture, fisheries, transport, internal market, research and technological development and space policies, the Union and the Member States shall, since animals are sentient beings, pay full regard to the welfare requirements of animals, while respecting the
}

explicit competence to the European Union including nature conservation. ${ }^{76}$ However, although environmental law became an EU competence, in most cases it is still crucial for the law binding on the area of each Member State as to how directives are implemented there. ${ }^{77}$

As to the trade in wild animals, the most important legal act with an impact on EU law is CITES, the provisions of which were implemented to EU law through two (already mentioned) regulations: Council Regulation (EC) No $338 / 97$ on the protection of species of wild fauna and flora, and Commission Regulation (EC) No 865/2006 (the implementing regulation $)^{78}$. The second of these not only sets out detailed rules concerning the implementation of the first one, but also includes provisions for animals born and bred in captivity.

Although Council Directive 98/58/EC on the protection of animals kept for farming purposes protects only animals kept for the production of food, wool, skin or fur, or for other farming purposes, it sets out rules for these animals that reflected the 'Five Freedoms': freedom from hunger and thirst; freedom from discomfort; freedom from pain, injury and disease; freedom to express normal behavior; and freedom from fear and distress. ${ }^{79}$ These freedoms, together with the content of Article $13 \mathrm{TFEU},{ }^{80}$ are the foundations for Member States to prohibit private individuals from keeping wild animals. Namely, it is the competence of the Member States to legislate on the subject of exotic pets. However, because of the several health and animal protection laws of the EU, all countries of the EU prohibit keeping wild animals and such cases are very rare nowadays. ${ }^{81}$ Legal provisions

legislative or administrative provisions and customs of the Member States relating in particular to religious rites, cultural traditions and regional heritage."

78 European Commission, An Introduction to CITES and its Implementation in the European Union (2010),

http://ec.europa.eu/environment/cites/pdf/trade_regulations/sho rt_ref_guide.pdf;

http://ec.europa.eu/environment/cites/legislation_en.htm.

79 For more information see the official website of European Commission in the field of animal welfare. European Commission, http:/ / ec.europa.eu/food/animals/welfare/index_en.htm. (last visited July 11, 2016).

${ }^{80}$ According to Art. 13 TFEU, introduced by the Treaty of Lisbon, "In formulating and implementing the Union's agriculture, fisheries, transport, internal market, research and technological development and space policies, the Union and the Member States shall, since animals are sentient beings, pay full regard to the welfare requirements of animals, while respecting the legislative or administrative provisions and customs of the Member States relating in particular to religious rites, cultural traditions and regional heritage."

${ }^{81}$ For example, between 1996 and 2002 in the UK there were just 6 wildlife trade prosecutions according to M. Engler, R. Parry-Jones. See: Maylynn Engler, Rob Parry-Jones, Opportunity or Threat - the Role of the European Union in Global Wildlife Trade (2007), available under:

https: / / www.google.pl/url?sa=t\&rct=j\&q=\&esrc=s\&source=web\&c $\mathrm{d}=1$ \&ved=0ahUKEwiQ5e_RjuzNAhXsIpoKHdMaB2AQFggiMAA\& url =http $\% 3 \mathrm{~A} \% 2 \mathrm{~F} \% 2 \mathrm{Fstatic} 1.1$. sqspcdn.com $\% 2$ Fstatic $\% 2 \mathrm{Ff} \% 2 \mathrm{~F} 157301$ \%2F2327381\%2F1231166092210\%2Ftraffic_pub_trade15.pdf\%3Ftoken \%3D7jSJGvv2Yf3U6tJJ502OBK8GyjI\%253D\&usg=AFQjCNHTkYiLN ouuE-zngQO4CidS6XElrQ\&sig2=JQD-oCBTsRk-XJRVTivIgA. 
may ban the keeping of certain species of animals (negative or black list), or allow only certain species to be kept (positive or white list). Keeping may also require authorization in the form of a license. ${ }^{82}$

For example, in Austria wild cats cannot be kept anywhere except qualified zoos, and keeping wild animals is generally forbidden. ${ }^{83}$ In Greece, the law prohibits holding and keeping wild animals as personal or household pets. ${ }^{84}$ In Denmark, no animal species that may present a danger or whose welfare is particularly difficult to maintain may be kept by a private person, and all species of predators are banned from private ownership, with certain exceptions that do not include big cats. ${ }^{85}$ In Belgium and the Netherlands, there is an innovative solution based on a "positive list" of animals that may be kept as pets - the wild animals species that are not prohibited to be kept by private persons are listed in a legal act. In Belgium, the government adopted a positive list for mammals comprising forty-two species in $2011 .^{86}$ In the Netherlands, the "positive list" of animals that may be kept as pets came into force in February 2015. ${ }^{87}$ However, in most EU countries (including Poland), wildlife protection equals a prohibition on keeping wild animals without a permit. ${ }^{88}$ All EU countries also set out sanctions and provide enforcement for the presented legislation.

In the European Union, in addition to the regulations implementing CITES, there are also other legal acts protecting wildlife. The most important of these are Council Directive 79/409/EEC of 2 April 1979 on the conservation of wild birds (known as the "Birds Directive") and Council Directive 92/43/EEC of 21 May

\section{Animal Friends Croatia, http://www.prijatelji-} zivotinja.hr/index.en.php?id=1759 (last visited July 11, 2016).

${ }^{83}$ Edith Palmer, Regulations Concerning the Private Possession of Big Cats - Austria, The Law Library Of Congress (July 11, 2016), https://www.loc.gov/law/help/bigcats/austria.php;

Bundeskanzleramt

https://www.help.gv.at/Portal.Node/hlpd/public/content/133/Se ite.1330000.html\#prohibition (last visited July 11, 2016).

${ }^{84}$ Theresa Papademetriou, Regulations Concerning the Private Possession of Big Cats - Greece, The Law Library Of Congress (July 11, 2016), https://www.loc.gov/law/help/bigcats/greece.php

${ }^{85}$ Wendy Zeldin, Regulations Concerning the Private Possession of Big Cats - Denmark, The Law Library Of Congress (July 11, 2016), https://www.loc.gov/law/help/bigcats/denmark.php.

${ }^{86}$ Endcap, The Use of Positive Lists to Identify Exotic Species Suitable to be Kept as Pets in the EU - Summary, ENDCAP (July 11, 2016), http:/ / endcap.eu/wild-pets-in-the-eu/.

${ }^{87}$ ENDCAP (July 11, 2016), http://endcap.eu/restriction-on-exotic-pets-inthe-netherlands/.

${ }^{88}$ For example in Poland - based on the Animal Protection Statute (Ustawa o ochronie przyrody), in France - based on the Environment Code, in England - based on the Dangerous Wild Animals Act, see: Animal Protection Index (July 11, 2016), http://api.worldanimalprotection.org.

${ }^{89}$ Ludwig Kraemer, EU Environmental Law 187-93 (2012).

90 European Commission, An Introduction to CITES and its Implementation in the European Union (2010),

http://ec.europa.eu/environment/cites/pdf/trade_regulations/sho rt_ref_guide.pdf.
1992 on the conservation of natural habitats and of wild fauna and flora (known as the "Habitats Directive"), which form the cornerstone of Europe's nature conservation policy and build a Natura 2000 network of protected areas. ${ }^{89}$ Although the Natura 2000 network is not focused on keeping wild animals, it supports the same ideas as CITES and prohibits trade in certain species. These two directives are also the main reason why the regulations implementing CITES convention into EU law (Council Regulation (EC) No. 338/97 and the Commission Regulation (EC) No. 865/2006) contains some non-CITES listed species ${ }^{90}$.

In my opinion, it is the internal law of the EU rather than the provisions of CITES itself that make CITES work in Europe. The EU as a whole first became a party to CITES in $2015,{ }^{91}$ though the internal law of EU already provided much stricter import conditions than those imposed by CITES before becoming its signatory. ${ }^{92}$ The statistics shown in the Traffic Europe Report from $2007^{93}$ should not, therefore, be treated as a reliable source of EU wildlife trade regulations before the EU became a party to CITES, as the report showing the EU as "one of the largest and most diverse markets in the world for live species, their products and derivatives," was published before the second EU regulation implementing CITES ${ }^{94}$ and the Lisbon Treaty came into force.

The two latter legal acts are the best proof of the EU's ongoing attempts to provide better protection for wild animals. Additionally, it should be taken into account that EU, which in most cases comes under accusations of lack of appropriate protection of wild fishes ${ }^{95}$ and timber, ${ }^{96}$

91 CITES (July 11, 2016), https://www.cites.org/eng/disc/parties/chronolo.php.

92 European Commission, An Introduction to CITES and its Implementation in the European Union (2010),

http://ec.europa.eu/environment/cites/pdf/trade regulations/sho rt_ref_guide.pdf.

${ }^{93}$ Maylynn Engler, Rob Parry-Jones, Opportunity or Threat - the Role of the European Union in Global Wildlife Trade (2007), available under:

https: / / www.google.pl/url?sa=t\&rct=j\&q=\&esrc=s\&source=web\&c $\mathrm{d}=1 \&$ ved=0ahUKEwiQ5e_RjuzNAhXsIpoKHdMaB2AQFggiMAA\& url=http $\% 3 \mathrm{~A} \% 2 \mathrm{~F} \% 2$ Fstatic1.1.sqspcdn.com $\% 2$ Fstatic $\% 2 F f \% 2 F 157301$ \%2F2327381\%2F1231166092210\%2Ftraffic_pub_trade15.pdf\%3Ftoken \%3D7jSJGvv2Yf3U6tJJ502OBK8GyjI\%253D\&usg=AFQjCNHTkYiLN ouuE-zngQO4CidS6XElrQ\&sig2=JQD-oCBTsRk-XJRVTivIgA.

${ }^{94}$ The Commission Regulation (EC) No. 865/2006 of May 4, 2006 laying down detailed rules concerning the implementation of Council Regulation (EC) No 338/97 on the protection of species of wild fauna and flora by regulating trade therein ("the implementing regulation"). ${ }^{95}$ See: Ludwig Kraemer, EU Environmental Law 193 (2012), in order to learn more about the Council Directive 78/659 of July 18, 1978 on the quality of fresh waters needing protection or improvement in order to support fish life, OJ L222/1 and Directive 79/923 of December 12, 2006 on the quality required of shellfish waters, OJ L281/47, which completely failed in the opinion of the author.

${ }^{96}$ In fact, forestry is not part of the Common Agricultural Policy and trees and forestry products do not normally come under the notion of "agricultural products" - see more: Ludwig Kraemer, EU Environmental Law 183 (2012). See also: Sara F. Oldfield, The Evolving Role of CITES in Regulating the International Timber Trade, 22 Review Of 
does in fact have less strong legal protection for these living species, but this does not have any impact on the EU trade in wild animals and a prohibition on keeping them as pets throughout the EU. Here, it is also worth mentioning that the process of imposing increasingly strict and efficient wildlife protection in the EU is still going on today - just on February 26, 2016 the European Union launched a new Action Plan Against Wildlife Trafficking. ${ }^{97}$

\section{CONCLUSION}

A new poll revealed that the majority of Americans oppose trophy hunting, following death of Cecil the Lion. What is more, two-thirds of Americans support listing African lions under the Endangered Species Act to give the species greater federal protections, and 64 per cent support placing restrictions on trophy hunting of native animals, such as bobcats and mountain lions. ${ }^{98}$ It is not possible to protect wild animals in one state, without protecting them in another. It is also not possible to successfully prevent the trade of wild animals without prohibiting them from being kept as pets. The case of Cecil the lion showed that Americans want to have stricter laws on the protection of wild animals, but might easily be confused in the face of the large number of laws concerning the protection of wild animals. Thus, they are not only different in each state, but they also different when it concerns a global protection of the wild species and keeping them in homes.

As we can conclude, basing on the presented material - it is not necessary important which convention a particular country is a party to, but how certain laws are implemented. Although the EU as a whole was not a party to CITES until 2015, it was much less common for private individuals to keep wild animals in Europe than in the US even before that. And although the law on the sale of animals leads to similar solutions in Europe, even though it is based on different legal systems (common law and civil law countries), it leads to totally different solutions concerning the law on wild animals.

Wildlife trade gives too many incentives to those who are enriched by breaking its rules - especially when taking into account the lack of information and public knowledge in most countries popular for the exportation of wild animals. Thus, it is very questionable whether it will ever be possible to finally stop the trade in wildlife. Unfortunately,

European Comparative \& International Environmental Law 291-300 (2013).

97 Eurogroup For Animals, http:/ / www.eurogroupforanimals.org/eurogroup-for-animalscalls-for-a-commitment-to-implement-the-limited-animal-welfareprovisions-of-eu-vietnam-fta-2/ (last visited July 11, 2016).

${ }_{98}$ Humane Society Of The United States,

http://www.humanesociety.org/news/press_releases/2015/10/pol l-americans-opose-trophy-hunting-

100715.html?credit=web_id93480558 (last visited Nov. 11, 2015).

99 R. B. Martin, When CITES Works and When it Does Not, in Endangered Species, Threatened Convention: The Past, Present And Future Of CITES (Jon Hutton, Barnabas Dickson eds., 2000).
CITES is not considered to be the best solution for protecting wild animals - it has not yet been shown that there are any species that have improved their status because of the provisions of the convention. What is more, the only species that seem to profit from CITES are those where in fact CITES failed on its protection and different factors incurred (for example, the status of the Nile crocodile [Crocodylus niloticus] improved not as a result of applying CITES, but only when CITES shifted from a policy of restricting trade to one of promoting the sustainable use of crocodile; ${ }^{99}$ the same situation happened in the case of the black rhino [Diceros bicornis], whose population increased when the trade ban failed ${ }^{100}$ ).

The European Union as a whole implemented the CITES convention and continues to improve the provisions of laws implementing CITES anytime it observes that certain provisions did not work as well as they were supposed to. By contrast, the US has been a party to CITES for a longer time, but the control of wildlife is not as effective, which might be caused by the lack of centralized control or the lack of its popular acceptance. ${ }^{101}$ There are no perfect laws, and there will always be people willing to try to circumvent it, but if the law is different in every state, it cannot be consistent. It can also not be respected - if there are no controls at state borders, there is no problem in buying a wild animal in Nevada and driving it to California. What is more, not only is the material law lacking, but also provisions concerning its enforcement, which are necessary in order to ban the trade in wild animals and keeping them as pets. Even if the wording of the law remains the same, the legal result is still not guaranteed - this can be achieved only through a uniform interpretation and effective enforcement of law in all the states of America.

Taking all this into account, I think that the EU, despite not having perfect laws, is much more effective in prohibiting the keeping of wild animals as pets and prohibiting the trade in wild animals. In order to achieve better results in this field of law (especially when keeping wild animals like big cats), the US should implement legal provisions that are consistent in all states. What is more, its interpretation, application and enforcement should also be the same.

$$
--0--
$$

100 Id. at 34.

101 See: Dangerous Wild Animals Laws, Humane Society Of The United States (2015), http://www.humanesociety.org/assets/pdfs/wildlife/exotics/state -laws-dangerous-wild-animals.pdf in order to observe the lack of consistency in the US state laws concerning the legality of keeping wild animals as pets and: R. B. Martin, When CITES Works and When it Does Not, in Endangered Species, Threatened Convention: The Past, Present And Future Of CITES 31-32 (Jon Hutton, Barnabas Dickson eds., 2000). 
How to Cite: Lubelska-Sazanów, M. (2018). The Wild Differences in Law when Trading in Wild Animals: a US and EU Perspective. American Journal of Trade and Policy, 5(2), 39-48.

\section{SOCIAL SCIENCE RESEARCH NETWORK}

2171 Monroe Avenue, Suite 203, Rochester, NY 14618, USA http://www.ssrn.com/en/

SSRN Link: http://www.ssrn.com/link/American-Journal-Trade-Policy.html 